\title{
Anaemia prevalence and dietary intake of elderly persons living in a peri-urban settlement in South Africa
}

\author{
Wilna H Oldewage-Theron, Folake Samuel, Christa Grobler \& AA Egal
}

\section{Opsomming}

Anemie in bejaardes het verskeie negatiewe gevolge vir gesondheid, algemene welstand en langslewendheid. Bejaardes wat in peri-stedelike woongebiede woon is veral blootgestel aan risikos as gevolg van voedsel en voeding insekuriteit wat verband hou met armoede en dus lei tot ' $n$ koolhidraatryke dieet laag in yster, folaat en vitamien $B_{12}$. Hierdie studie ondersoek die voorkoms van anemie en die verband tussen dieetinname van verskeie nutriënte en anemie soos gemeet in ' $n$ steekproef van 138 swart, bejaarde respondente wat in ' $n$ peristedelike gebied woon in Suid Afrika. Bloedmonsters is gekollekteer en geanaliseer vir hemoglobien, hematokrit, gemiddelde korpuskulêre volume, rooi bloedsel telling, serum ferritien, transferrien, serum yster, serum folaat en serum vitamien $B_{12}$. Liggaamsmassa indeks is bepaal deur antropometriese metings en dieetinnames deur middel van 'n 24-uur herroep. Data analises is gedoen op die "Statistical Package for Social Sciences (SPSS)" vir "Windows" uitgawe 15,0. Biochemiese parameters was vergelyk met verwysingswaardes. Gemiddeldes, standaard afwykings en mediane is vir elke parameter bepaal. Dieet innames en voedsel verbruikerspatrone is geanaliseer deur ' $n$ geregistreerde dieetkundige deur middel van die Foodfinder ${ }^{\circledR}$ edisie 3 program, wat deur die Mediese Navorsingsraad van Suid Afrika ontwikkel is. Die Levene's t-toets vir gelykheid van variansies was gedoen om verskille in gemiddeldes tussen mans en vrouens te bepaal en Pearson korrelasie koeffisiente was gedoen om assosiasies tussen die studie parameters te ondersoek. Die mans het betekenisvolle hoër gemiddelde waardes gehad $(p \leq 0,05)$ as die vrouens vir serum hemoglobien, hematokrit en ferritien. Die voorkoms van ystertekortanemie was $12,5 \%$ in die mans en $13,2 \%$ in die vroue, en $8,3 \%$ en $4,4 \%$ mans en vroue respektiewelik het makrositiese anemie gehad. Lae serum folaat het meer voorgekom by vroue $(32,5 \%)$ as mans $(20,8 \%)$, en lae serum vitamien $B_{12}$ was in $29,2 \%$ van die mans en $10,5 \%$ van die vroue waargeneem. Die dieet van beide die mans en vroue was hoofsaaklik saamgestel uit koolhidrate, maar dieet tekorte van yster, sink en vitamien $B_{12}$ was groter by die vroue as die mans. Serum vitamien $B_{12}$ was positief geassosieer met dieet folaat en vitamien $B_{12}$ innames en serum folaat het ' $n$ positiewe verband getoon met dieet inname van slegs vitamien $B_{12}$. Geen betekenisvolle korrelasies is egter tussen yster status indikators en dieet inname waargeneem nie. Dit wil voorkom asof bejaarde vroue ' $n$ groter risiko het om anemie te ontwikkel en het meer waargeneemde yster en folaat tekorte. Die tekort aan sistematiese studies in hierdie snel groeiende populasie groep skep 'n probleem vir die ontwikkeling van geskikte voeding intervensies en die resultate van hierdie studie sal aangewend word vir die beplanning en implementering van volhoubare intervensie programme in hierdie bejaarde gemeenskap.

\section{- Prof WH Oldewage-Theron}

Institute of Sustainable Livelihoods Vaal University of Technology Vanderbijlpark

\section{- Dr F Samuel}

Institute of Sustainable Livelihoods Vaal University of Technology Vanderbijlpark

\section{- Ms C Grobler}

Department of Biomedical Sciences Vaal University of Technology Vanderbijlpark

\section{- Dr AA Egal}

Institute of Sustainable Livelihoods Vaal University of Technology Vanderbijlpark 


\section{INTRODUCTION}

In the elderly, anaemia is a very common problem that is associated with increased mortality and poorer health-related quality of life, regardless of the underlying cause of the low haemoglobin (Steensma \& Tefferi, 2007). Prevalence figures of anaemia in the elderly vary among different countries. Guralink et al (2004) reported anaemia prevalence of $11 \%$ and $10,2 \%$ in free-living men and women aged 65 years and above in the United States. Another study carried out in the Netherlands showed that $28 \%$ and $17 \%$ of men and women aged 85 years and above were anaemic (Izaks et al, 1999). In South Africa, Charlton and co-authors (1997) documented a prevalence of $13,9 \%$ in a population of elderly persons of mixed ancestry (Afro-Euro-Malay).

Accumulating evidence exists on the consequences of anaemia in the elderly, ranging from a general perspective regarding its negative impact on quality of life (Ross et al, 2003), to specifics such as diminished cognitive function (Chaves et al, 2006) and decreased physical performance and muscle strength (Penninx et al, 2003). Poorer health outcomes have also been connected with anaemia in the elderly. For instance, in elderly patients with heart failure, lower haemoglobin levels have been associated with more symptoms, poorer haemodynamics and greater mortality than higher haemoglobin levels have (Ezekowitz et al, 2003; Horwich et al, 2002). Similarly, Dharmarajan and Norkus (2004:395) described elevated risks for falls and fractures among those with even mild anaemia or low-normal haemoglobin levels.

According to the World Health Organization (WHO, 2001), anaemia occurs when haemoglobin levels fall below $13 \mathrm{~g} / \mathrm{dl}$ in men and $12 \mathrm{~g} / \mathrm{dl}$ in women. The diversity of potential factors contributing to anaemia among the elderly, such as renal insufficiency, chronic inflammation, primary disorders of haematopoiesis, use of medication and abuse of alcohol, make it particularly challenging to study the condition in this group of people (Steensma \& Tefferi, 2007). However, even though there may be many causes of anaemia, dietary iron deficiency is often either the main or a major contributing factor, while other micronutrient deficiencies (e.g. low intakes of folic acid and vitamins $A, B_{12}$, and C) may also play a role (WHO, 2001). Dietary inadequacies of iron are likely to occur in situations where, because of economic constraints, staple diets are predominantly plant-based, poor in iron and of low iron bio-availability (Gibson \& Ferguson, 2000). Low economic status has been associated with a higher risk of anaemia (El-Sayed et al, 1999; Sargent et al, 1996). In South Africa, black elderly people living in informal settlements are typically poor and have very limited resources to maintain health and well being (Engelbrecht \& Du Rand, 2001). Informal settlements are usually peri-urban, and a growing number of studies are drawing attention to the existence of high levels of poverty together with chronic food insecurity in various informal settlements in South Africa (Dannhauser et al, 2000; Hugo-Hamman et al, 1987; Oldewage-Theron et al, 2004). Notably, not much has been done in South Africa to study the prevalence and aetiology of anaemia among elderly people living in such environments. More research is needed in this regard in order to provide information upon which to base intervention strategies for this vulnerable section of the population.

The purpose of this study was to evaluate the prevalence of anaemia in relation to the dietary intake of a population of elderly people living in Sharpeville, a peri -urban community in South Africa.

\section{METHODS}

\section{Target population}

This project was undertaken amongst the elderly attending a day-care centre in Sharpeville, situated in the Vaal region of South Africa. The day-care centre offers skills training and religious activities aimed at the low-income elderly (aged 60 years and above) in order to assist in income-generation. An earlier study had established the high prevalence of poverty, food insecurity, malnutrition and poor health in the Vaal region (Oldewage-Theron et al, 2006). The sample size calculation (The Survey System) used for this study was as follows:

$$
Z^{2 *}(p) *(1-p)
$$

Sample size $=$

$$
c^{2}
$$

where:

$Z=Z$ value (e.g. 1,96 for $95 \%$ confidence level) $p=$ percentage picking a choice, expressed as decimal

( $p=0,5$ used for sample size needed)

$c=$ confidence interval, expressed as decimal $($ eg. $0,05=5)$

A total of 196 respondents were thus needed for this cross-sectional survey to obtain statistically representative data for this community. However, 235 out of 400 elderly persons (59\%) attending this faith-based day-care centre gave their written consent to participate in the study. The study was approved by the University of the Witwatersrand's Medical Ethics Committee for research on human beings (R14/49).

A limitation of this study was that not all measurements could be taken on the same days, owing to the low attention span of the elderly. As a result, because of the irregular attendance of some of the respondents at the day care centre, a complete set of data for all the respondents could not be obtained and only 138 questionnaires (purposive sample from the respondents who gave consent) were completed and used for the data analyses. The power calculation for a sample size of 138 had to be adjusted to a confidence level of $95 \%$ and a confidence interval of 6,75 (The Survey System). 
A further limitation of this study was that no ethics approval had been obtained for human immunodeficiency virus (HIV) / auto-immunity deficiency syndrome (AIDS) testing and this was thus not included in this study.

\section{Data collection}

Measurements were taken during March 2007. This study forms part of a larger project named, in Sotho, a South African language, 'Ja Hantle Obe Mafolofolo' (adapted from the Florida International University programme entitled: Eat Better and Move More).

Anthropometric, haematological and dietary data were obtained from the sample of elderly respondents $(n=138)$. Weight and height were measured using standard measurements, and body mass index (BMI) was calculated as weight $(\mathrm{kg})$ divided by height squared $\left(\mathrm{m}^{2}\right)$. Venous blood samples were drawn to determine biochemical indices of the respondents. Blood was drawn from the vena cephalica of seated respondents after an eight-to-twelve-hour fast, using a Vacutainer needle with minimal use of tourniquets. A qualified nursing sister collected the blood sample. The blood was separated within two hours of its collection. Separated plasma and serum were aliquoted in marked Eppendorf test tubes. The following analyses were performed: serum iron (colorimetric, Konelab ${ }^{\mathrm{TM}}$ Iron), ferritin (immunoturbidometric method, TOSOH AIA FERR), haemoglobin (cyanmethaemoglobin-colorimetric method), haematocrit (numeric integration), red cell count (cell-counting auto analyser), transferrin (immunoprecipitation, Konelab ${ }^{\mathrm{TM}}$ ), serum folate (immunoturbidity TOSOH $\mathrm{AIA}$ ) and serum vitamin $\mathrm{B}_{12}$ (immunoturbidity $\mathrm{TOSOH}$ AIA).

Measuring serum and erythrocyte folate levels usually determine folate status, although serum or plasma homocysteine is increasingly used as a functional test for folate deficiency (Gibson, 2005:599-600). The ad- vantage of using serum for determining folate status, however, is that it is not expensive or time-consuming (Carlson, 2004:445) and was used in this study for these reasons. Furthermore, because of the possibility of a co-existing vitamin $B_{12}$ deficiency, it is recommended that serum folate and vitamin $B_{12}$ should always be tested together (Gibson, 2005:600). Vitamin $B_{12}$ is also measured in serum (Carlson, 2004:445).

A limitation of this study was that a quantified food frequency questionnaire could not be used to determine habitual/usual dietary intake due to the low attention span of the elderly and the majority of the elderly respondents being illiterate $(75,8 \%)$. It was thus decided that trained fieldworkers would administer a structured 24-hour recall questionnaire, validated previously, for dietary assessment. Because breakfast and lunch were served on care centre attendance days, it was decided to complete the 24-hour recall on two days when the elderly did not attend the care centre so that the correct information could be obtained about their usual food consumption patterns and dietary intake at home. Food models were used to determine portion sizes and to explain food items to the respondents.

\section{Data analysis}

Biochemical indicators were compared to cut-offs. Means and standard deviations were computed for each variable. Data analysis was done using the Statistical Package for Social Sciences (SPSS) for Windows version 15,0. Dietary intake and food consumption data were analysed by a registered dietician using the Foodfinder ${ }^{\circledR}$ version 3 program, developed by the Medical Research Council of South Africa. The Levene's t-test for equality of variances was used to evaluate differences in means between men and women, and Pearson's correlation coefficients were used to examine associations between the study variables $(p \leq 0,05)$.

TABLE 1: DEMOGRAPHIC AND ANTHROPOMETRIC DATA OF ELDERLY MEN $(\mathrm{n}=24)$ AND WOMEN ( $n=114$ (Descriptive statistics - means, standard deviations, frequencies)

\begin{tabular}{|c|c|c|c|}
\hline Variable & Men \% & Women \% & Total group \% \\
\hline $\begin{array}{l}\text { Age (years) } \\
\text { Mean } \\
\text { Standard Deviation (SD) } \\
\text { Minimum } \\
\text { Maximum }\end{array}$ & $\begin{array}{r}72,7 \\
7,0 \\
60,0 \\
89,0\end{array}$ & $\begin{array}{r}73,5 \\
8,4 \\
60,0 \\
93,0\end{array}$ & $\begin{array}{c}73,4 \\
8,2 \\
60,0 \\
93,0\end{array}$ \\
\hline $\begin{array}{l}\text { Body Mass Index } \\
\text { Mean } \\
\text { Standard Deviation (SD) } \\
\text { Minimum } \\
\text { Maximum }\end{array}$ & $\begin{array}{r}25,7^{*} \\
4,6 \\
19,4 \\
41,0\end{array}$ & $\begin{array}{r}29,9^{*} \\
6,4 \\
16,0 \\
46,2\end{array}$ & $\begin{array}{c}29,3 \\
6,4 \\
16,0 \\
46,2\end{array}$ \\
\hline $\begin{array}{l}\text { BMI Classification (\%) } \\
\text { Underweight }(<18.5) \\
\text { Normal }(\geq 18.5<24.99) \\
\text { Overweight }(\geq 25<29.99) \\
\text { Obese }(\geq 30) \\
\text { Total }\end{array}$ & $\begin{array}{r}1,5 \\
65,8^{*} \\
18,4^{*} \\
15,8^{*} \\
100,0\end{array}$ & $\begin{array}{c}0,0 \\
20,8^{*} \\
30,5^{*} \\
47,2^{*} \\
100,0\end{array}$ & $\begin{array}{c}1,3 \\
28,1 \\
28,5 \\
42,1 \\
100,0\end{array}$ \\
\hline
\end{tabular}

* Significant differences between men and women $(p \leq 0,05)$ (Levene's t-test of equality of variances) 
TABLE 2: $\quad$ BIOCHEMICAL PARAMETERS OF ELDERLY MEN AND WOMEN RESPONDENTS $(\mathrm{n}=138)$

\begin{tabular}{|c|c|c|c|c|c|}
\hline \multirow[t]{2}{*}{ Indicator } & \multirow[t]{2}{*}{ Normal values } & \multicolumn{2}{|c|}{ Men (n=24) } & \multicolumn{2}{|c|}{ Women (n=114) } \\
\hline & & MeantSD & Range & Mean \pm SD & Range \\
\hline $\begin{array}{l}\text { Haemoglobin } \\
(\mathrm{g} / \mathrm{l}) \#\end{array}$ & $\begin{array}{l}13,5-17,5 \mathrm{~g} / \mathrm{dl}(\mathrm{m}) \\
11,5-15,5 \mathrm{~g} / \mathrm{dl}(\mathrm{w})\end{array}$ & $13,8 \pm 1,3^{\star}$ & $10,4-17,6$ & $13,2 \pm 1,2^{*}$ & $9,9-17,8$ \\
\hline $\begin{array}{l}\text { Haematocrit (\%) } \\
\#\end{array}$ & $\begin{array}{l}40-52 \%(\mathrm{~m}) \\
36-48 \%(\mathrm{w})\end{array}$ & $42,7 \pm 4,2^{\star}$ & $31,2-55,0$ & $40,6 \pm 3,4^{\star}$ & $30,7-52,2$ \\
\hline $\begin{array}{l}\text { Mean corpuscular } \\
\text { volume (fl) } \wedge\end{array}$ & $81-98$ & $91,7 \pm 6,0$ & $84,1-100,5$ & $100,1 \pm 85,1$ & $30,3-111,8$ \\
\hline $\begin{array}{l}\text { Red blood cell } \\
\text { count }\left(\times 10^{12} /\right)^{\wedge}\end{array}$ & $4,4-5,6$ & $4,7 \pm 0,6$ & $3,4-6,5$ & $4,4 \pm 0,4$ & $3,1-5,8$ \\
\hline $\begin{array}{l}\text { Serum ferritin } \\
(\mu \mathrm{g} / \mathrm{l}) \S\end{array}$ & $\begin{array}{l}18-250 \mathrm{ng} / \mathrm{ml}(\mathrm{m}) \\
12-160 \\
\mathrm{ng} / \mathrm{ml}(\mathrm{w})\end{array}$ & $166,0 \pm 222.1^{*}$ & $5,7-764,6$ & $123,4 \pm 136,9^{*}$ & $2,35-981,3$ \\
\hline Transferrin $(\mathrm{g} / \mathrm{l}) \S$ & $2,0-3,6 \mathrm{~g} / \mathrm{l}$ & $2,4 \pm 0,7$ & $0,3-3,8$ & $2,2 \pm 0,9$ & $0,3-6,4$ \\
\hline $\begin{array}{l}\text { Serum Iron } \\
(\mu \mathrm{mol} / /) \#\end{array}$ & $\begin{array}{l}11,6-31,3 \mu \mathrm{mol} / /(\mathrm{m}) \\
9,0-30,4 \mu \mathrm{mol} / \mathrm{l}(\mathrm{w})\end{array}$ & $12,7 \pm 5,2$ & $4,1-22,1$ & $11,4 \pm 8,6$ & $1,0-33,2$ \\
\hline $\begin{array}{l}\text { Serum Folate } \\
(\mathrm{nmol} / \mathrm{l}) \Pi\end{array}$ & $5,9-45,4 \mathrm{nmol} / /$ & $3,4 \pm 2,2$ & $1,2-8,8$ & $4,2 \pm 2,3$ & $1,0-14,6$ \\
\hline $\begin{array}{l}\text { Serum Vitamin } \\
\mathrm{B}_{12}(\mathrm{pmol} / \mathrm{l}) \boldsymbol{\Pi}\end{array}$ & $156-672 \mathrm{pmol} / /$ & $284,8 \pm 181,6^{*}$ & $57,0-902,0$ & $389,4 \pm 246,1^{*}$ & $12,4-1568,0$ \\
\hline
\end{tabular}

${ }^{*}$ Statistically significant differences for biochemical variables between men and women at $p \leq 0,05$ (Levene's test of equality of variances)

(\#Hoffbrand et al., 2001:331; §Konelab 20i reagent Kits; ๆ \& ^SA Medical Research Council)

\section{RESULTS}

In Table 1, the anthropometric characteristics of the respondents are presented. There were more women $(82,6 \%)$ than men $(17,4 \%)$, and the age of the respondents ranged between 60 and 93 years, with the mean age being $73,4 \pm 8,16$. While the majority of the men respondents $(65,8 \%)$ had normal body mass index (BMI) values, only $20,8 \%$ of the women had normal BMI values while $30,5 \%$ and $47,2 \%$ of the women were overweight and obese respectively. Mean BMl was significantly higher $(p=0,000)$ for women than men.

Table 2 shows the serum biochemical parameters of the respondents stratified by gender. Most of the mean values fell within normal ranges, except for serum folate levels that were low in both men and women. Men had higher mean values than the women for most of the parameters measured except for mean cell volume, serum folate and vitamin B12. Statistically significant differences between men and women were, however, observed in serum haematocrit, haemoglobin, ferritin and vitamin $B_{12}$ levels $(p \leq 0,05)$ when equal variances were not assumed (Levene's test for equality of variances). The women had significant lower serum values of the mentioned variables than the men, except for serum vitamin $B_{12}$.

Using cut-off values for abnormal biochemical indices, the proportion of individuals with deficient values are shown in Table 3. The prevalence of anaemia (based on haemoglobin values) was $12,5 \%$ in men and 13,2 $\%$ in women. Depleted iron stores (based on serum ferritin levels) occurred in $8,3 \%$ and $7,9 \%$ of men and women respectively, while $8,3 \%$ of the men had increased levels $(>250 \mathrm{ng} / \mathrm{ml}$ ) compared to $5,3 \%$ of the women $(>160 \mathrm{ng} / \mathrm{ml})$. A significant positive correlation $(r=0,203)$ was found between the respondents with iron deficiency anaemia (low haemoglobin values) and those with low iron stores (low serum ferritin levels) $(p=0,018)$, thus indicating that those respondents with low iron stores already presented iron deficiency anaemia in both genders.

The prevalence of microcytosis (based on mean corpuscular volume $<81 \mathrm{fl}$ ) was only prevalent in men $(4,2 \%)$ compared to macrocytosis (based on mean corpuscular volume $>98 \mathrm{fl}$ ) which was prevalent in $8,3 \%$ of the men and $4,4 \%$ of the women. The sample further showed a lower prevalence of vitamin $\mathrm{B}_{12}$ deficiency for the women $(10,5 \%)$ compared to the men $(29,2 \%)$, whereas the prevalence of folate deficiency was higher in women $(32,5 \%)$ than in the men $(20,8 \%)$.

Regarding the dietary assessment, the main source of food intake was starchy foods (maize meal porridge, brown bread and rice) that provided carbohydrates. Chicken and beef, good sources of iron and vitamin $B_{12}$, and milk, a good source of folate and vitamin $B_{12}$, appeared as protein sources, although these were consumed by a minority of the elderly. Fruit (apples and oranges) and vegetables (cabbage and spinach) also appeared on the Top 20 food consumption list. Although spinach is a good source of both iron and folate, the portion sizes were very small ( $49 \mathrm{~g}$ per day) and consumed by only $13 \%$ of the respondents. The total fruit and vegetable intake did not meet the recommended intake of $400 \mathrm{~g}$ per day. The only vitamin C-rich food item that appeared on the Top 20 most frequently consumed food items was orange/orange juice, but this was consumed by only $9 \%$ of the elderly, however the portion size was good (189 g/319 $\mathrm{ml}$ ). No dried beans, a good source of folate and iron, or organ meat, a good source of iron and vitamin $\mathrm{B}_{12}$, was included in the Top 20 most frequently consumed food items. 
TABLE 3:

PREVALENCE OF ABNORMAL BIOCHEMICAL INDICES OF ELDERLY MEN AND WOMEN $(n=138)$

\begin{tabular}{|c|c|c|}
\hline \multirow[t]{2}{*}{ Biochemical indices } & \multicolumn{2}{|c|}{ Prevalence of abnormal indices (\%) } \\
\hline & Men (n=24) & Women (n=114) \\
\hline Anaemia [Cut-off point $\mathrm{Hb}<13 \mathrm{~g} / \mathrm{l}$ (men), $<12 \mathrm{~g} / \mathrm{l}$ (women)] & 12,5 & 13,2 \\
\hline $\begin{array}{l}\text { Mean corpuscular volume } \\
\text { Microcytosis }(<81 \mathrm{fl})^{\wedge} \\
\text { Macrocytosis }(>98 \mathrm{fl})^{\wedge}\end{array}$ & $\begin{array}{l}4,2 \\
8,3\end{array}$ & $\begin{array}{l}0,0 \\
4,4\end{array}$ \\
\hline $\begin{array}{l}\text { Serum Ferritin } \\
\text { Low }[<12 \mathrm{ng} / \mathrm{ml}(\mathrm{w}) \text { and }<18 \mathrm{ng} / \mathrm{ml}(\mathrm{m})] \S \\
\text { Increased level }[>160 \mathrm{ng} / \mathrm{ml}(\mathrm{w}) \text { and }>250 \mathrm{ng} / \mathrm{ml}(\mathrm{m})] \S\end{array}$ & $\begin{array}{l}8,3 \\
8,3\end{array}$ & $\begin{array}{l}7,9 \\
5,3\end{array}$ \\
\hline $\begin{array}{l}\text { Serum Folate } \\
\text { Moderate deficiency }(9-16 \mathrm{nmol} /) \mathrm{T}\end{array}$ & 20,8 & 32,5 \\
\hline $\begin{array}{l}\text { Serum Vitamin } B_{12} \\
\text { Low }(<156 \mathrm{nmol} / \mathrm{L}) \mathrm{T} \\
\text { Borderline }(156-250 \mathrm{nmol} / \mathrm{L}) \mathrm{T}\end{array}$ & $\begin{array}{l}29,2 \\
25,0\end{array}$ & $\begin{array}{l}10,5 \\
15,8\end{array}$ \\
\hline
\end{tabular}

$\left({ }^{\star}\right.$ WHO, 2001; §Konelab 20i reagent Kits; II \& ${ }^{\wedge}$ SA Medical Research Council.

Accessed 24 Feb 2008])

TABLE 4: $\quad$ MEAN DAILY NUTRIENT INTAKES OF THE ELDERLY RESPONDENTS $(\mathrm{n}=138)$

\begin{tabular}{|c|c|c|c|c|c|}
\hline \multirow[t]{2}{*}{ Nutrient } & \multicolumn{2}{|c|}{ Men (n=24) } & \multicolumn{2}{|c|}{ Women(n=114) } & \multirow[b]{2}{*}{ DRI $\mathbf{I}^{* *}$} \\
\hline & $\begin{array}{l}\text { Mean } \pm \text { SD } \\
\text { (Range) }\end{array}$ & $<100 \%$ of EAR & $\begin{array}{l}\text { Mean } \pm \text { SD } \\
\text { (Range) }\end{array}$ & $<100 \%$ of EAR & \\
\hline Energy (kj) & $\begin{array}{c}7357 \pm 3913 \\
(2912-16501)\end{array}$ & 58,3 & $\begin{array}{c}6070 \pm 3328 \\
(1328- \\
12539)\end{array}$ & 59,6 & $\begin{array}{l}6182(w) \\
6809(m)^{\infty}\end{array}$ \\
\hline Protein (g) & $\begin{array}{c}87 \pm 53 \\
(18-189) \\
\end{array}$ & 20,8 & $\begin{array}{c}62 \pm 44 \\
(9-119) \\
\end{array}$ & 41,2 & 46,0 \\
\hline Total Iron (mg) & $\begin{array}{c}10,1 \pm 5,4 \\
(2,5-25,2)\end{array}$ & 8,3 & $\begin{array}{c}7,8 \pm 4,5 \\
(1,4-23,7)\end{array}$ & 29,5 & 5,0 \\
\hline Zinc (mg) & $\begin{array}{c}11,4 \pm 8,3 \\
(2,6-36,6)\end{array}$ & 37,5 & $\begin{array}{c}7,5 \pm 4,5 \\
(1,1-25,4)\end{array}$ & 57,1 & 6,8 \\
\hline Folate $(\mu \mathrm{g})$ & $\begin{array}{c}195,6 \pm 140,5 \\
(0,8-513,1)\end{array}$ & 87,5 & $\begin{array}{c}171,0 \pm 138,9 \\
(0,5-954,1)\end{array}$ & 91,1 & 320,0 \\
\hline $\begin{array}{l}\text { Vitamin } B_{12} \\
(\mu g)\end{array}$ & $\begin{array}{c}2,7 \pm 4,8 \\
(0,2-21,5)\end{array}$ & 66,7 & $\begin{array}{l}1,8 \pm 2,5 \\
(0-20,2)\end{array}$ & 75,9 & 2,0 \\
\hline Vitamin C (mg) & $\begin{array}{c}54,7 \pm 92,4 \\
(0-291,4)\end{array}$ & 75,0 & $\begin{array}{c}60,2 \pm 101,3 \\
(0-547,6)\end{array}$ & 76,8 & 60,0 \\
\hline
\end{tabular}

** Dietary Reference Intakes as represented by the Estimated Average Requirement for men and women aged 51-70 years old (Institute of Medicine, 2003).

$\infty$ Estimated energy requirements for sedentary men aged 71.3 years, height $=1.67 \mathrm{~m}$ and weight $=76.3 \mathrm{~kg}$ and women of 71.8 years, height $=1.6 \mathrm{~m}$ and $75.8 \mathrm{~kg}$.

No statistically significant differences were observed between the intakes of men and women at $p \leq 0,05$ (Levene's t-test of equality of variances).

Nutrient intakes are presented in Table 4. Men respondents had higher mean daily intakes than the women for all the reported nutrients, except for vitamin $\mathrm{C}$, though not at statistically significant levels $(p \leq 0,05)$. The results showed that in both the men and women, mean folate intakes were lower than the DRI, as well as for vitamin $C$ in men and vitamin $B_{12}$ and energy in women. Although the mean intakes showed adequate dietary intakes for protein, iron and zinc, a larger proportion of women than men did not meet $100 \%$ of the dietary reference intakes for these nutrients. The diets of approximately $87,5 \%$ of the men and $91,1 \%$ of the women did not meet the dietary reference intake for folate $(320 \mu \mathrm{g} / \mathrm{day})$. Although the mean dietary intakes met the DRI for zinc and iron, the data revealed that a large proportion of the respondents showed deficient intakes for these nutrients as $37,5 \%$ of the men and $57,1 \%$ of the women showed deficient intakes for zinc, and $66,7 \%$ of the men and $91,1 \%$ of the women for vitamin $B_{12}$. This can be due to the large range of nutrient intakes for the group of respondents. No statistically significant differences were observed between the dietary intakes of men and women $(p \leq 0,05)$.

Table 5 shows the relationships between biochemical variables and nutrient intake. Serum vitamin $B_{12}$, which was positively associated with intakes of dietary folate, zinc and vitamin $B_{12}$. In addition, serum folate was positively related to intake of dietary vitamin $B_{12}$ only. No other significant relationships existed between serum and dietary variables. However, relationships between dietary variables were significantly correlated $(\mathrm{Cl}=99 \%)$ as follows: vitamin $\mathrm{B}_{12}$ intake with zinc, iron and folate intakes, as well as iron intake with folate and zinc intakes. 

TAILED PEARSON CORRELATION ( $\mathrm{N}=138$ )

\begin{tabular}{|l|c|c|}
\hline Variable & Correlation $\mathbf{~}$ & Significance $\boldsymbol{p}$ \\
\hline Serum vitamin $\mathbf{B}_{12}$ with: & 0,252 & 0,002 \\
Dietary folate intake & 0,411 & 0,000 \\
Dietary zinc intake & 0,607 & 0,000 \\
Dietary vitamin $\mathrm{B}_{12}$ intake & & 0,001 \\
\hline Serum folate with: & 0,217 & 0,000 \\
Dietary vitamin $\mathrm{B}_{12}$ intake & & 0,000 \\
\hline Dietary vitamin $\mathbf{B}_{\mathbf{1}}$ intake with: & 0,521 & 0,000 \\
Dietary zinc intake & 0,527 & 0,000 \\
Dietary iron intake & 0,488 & 0,000 \\
Dietary folate intake & & 0,615 \\
\hline Dietary iron intake with: & 0,776 & \\
Dietary folate intake & & \\
Dietary zinc intake & & \\
\hline
\end{tabular}

\section{DISCUSSION}

This study is one of the few in the last ten years that provide data on biochemical and haematological indices of older black South African citizens. The paucity of data on the nutritional status of the elderly, not only in South Africa but Africa as a whole, has previously been pointed out (Charlton \& Rose 2001). The dearth of systematic studies in this rapidly increasing population group is obviously an obstacle to the development of appropriate nutrition interventions in this regard.

In this study, the database of women respondents was found to have a higher prevalence of anaemia $(13,2 \%)$ than men had (12,5\%). A previous study in South Africa reported values for elderly men $(11,4 \%)$ and women $(16,2 \%)$ of mixed ancestry (Charlton et al, 1997); these values exceed those of the women as found in our study. This study indicates that anaemia was found to be more of a problem in women than in men in this population of black elderly persons living in a poor peri-urban community in South Africa. Both genders also had a prevalence of macrocytic anaemia, but the prevalence was higher in men $(8,3 \%)$ compared to the women $(4,4 \%)$. In addition, vitamin $\mathrm{B}_{12}$ and folate deficiency were found to be common in these respondents. A study in Zimbabwe amongst the elderly also documented anaemia related to sub optimal folate status among community-dwelling elderly people (Allain et al, 1997). These were similar to the findings of this study.

Johnson and van der Westhuizen (1989) found that $21 \%$ of the women and $33 \%$ of the men in a sample of 100 elderly rural blacks in South Africa had low circulating vitamin $\mathrm{B}_{12}$ concentrations. A recent study also diagnosed low serum total vitamin $B_{12}$ in $6,1 \%$ and borderline total serum vitamin $\mathrm{B}_{12}$ in $32 \%$ of a population of 1048 aged people (65-100 years) in Finland (Loikas et al, 2007). In a study carried out among 218 institutionalised elderly people in Spain, moderate serum folate deficiency $(9-16 \mathrm{nmol} / \mathrm{l})$ was found to be $43,1 \%$, while deficient serum vitamin $B_{12}$ was $15,8 \%$ (Gonzalez-Gross et al, 2007). It thus appears that the elderly constitute a group at risk for these deficiencies as similar findings were found in this study.
In their review of available studies carried out on the nutritional status of South Africans (1975-1996), Vorster et al (1997:18) noted that although on a population level vitamin $B_{12}$ status appeared sufficient, it is possible that individuals or specific groups, such as vegetarians or the poorest of the poor, could have low intakes and low $B_{12}$ status because of insufficient intake of animal foods. In this regard, the data from our 24-hour recall analyses showed deficient intakes of energy, folate and Vitamin $C$ for a substantial proportion of the men, and energy, folate and vitamin $B_{12}$ in the women. A recent study amongst institutionalised elderly in Somerset-West showed low dietary intakes for energy, zinc, folate and vitamin $C$ in men and energy, folate and vitamin $B_{12}$ in women (Marais et al, 2007). Our findings indicated a diet that was largely carbohydrate-based, containing predominantly starchy staple foods but insufficient animal products, dairy foods, fruit and vegetables, possibly resulting in the observed deficiencies. These findings are consistent with the findings of the study undertaken in SomersetWest (Marais et al, 2007:107).

The information from the associations of nutrient intake together with serum data may provide support for this explanation. Serum vitamin $B_{12}$ was positively associated with intakes of dietary folate and vitamin $B_{12}$, and serum folate was positively related to intake of dietary vitamin $\mathrm{B}_{12}$. However, in this study no statistically significant correlations were observed between iron status indicators (serum ferritin, transferrin, haemoglobin and haematocrit) and dietary iron intake. Folate deficiency is most commonly due to poor diet, but it may also result from malabsorption. A folate and vitamin $B_{12}$ deficiency leads to the development of macrocytic anaemia, which is the second most common type of nutritional anaemia, after iron deficiency (Food and Agricultural Organization of the United Nations and the World Health Organization (FAO \& $\mathrm{WHO}, 2002: 13)$. Microcytic anaemia is mostly associated with iron deficiency whereas macrocytic anaemia is mostly caused by either folate- or vitamin $B_{12}$ deficient erythropoiesis (Carlson, 2004:443). Macrocytic or megaloblastic anaemia usually indicates an abnormal synthesis of deoxyribonucleic acid (DNA) and this results in morphologic and functional changes in the 
erythrocytes, leukocytes, platelets and their precursors in blood and bone marrow. Both vitamin $\mathrm{B}_{12}$ and folate are essential for the synthesis of the nucleoproteins and a deficiency of these nutrients will result in the same haematological changes, but the folate deficiency will appear within two to four months of an individual consuming a folate-deficient diet, whereas vitamin $B_{12}$ stores will be depleted after several years of a vitamin $B_{12}$-deficienct diet (Stopler, 2004:847). In this study both folate and vitamin $B_{12}$ deficiencies were prevalent in both genders and this could have been the cause of the macrocytic anaemia found in this elderly community.

Anaemia, together with deficiencies of folate and vitamin $B_{12}$, is an important issue facing the elderly studied in this poor peri-urban community. This is particularly so for the women, who have the additional problem of a predominantly unhealthy body mass index. This may imply associated health risks and a resultant economic burden for these low-income elderly women.

The issue assumes even greater importance when considering the current situation in South Africa, where $64 \%$ of children who have been orphaned by AIDS are being raised by grandparents (United $\mathrm{Na}-$ tions Children Fund, 2003:17). These elderly people, typically the grandmothers, themselves often poor and weakened with age, and facing stigmatisation and emotional problems as well as new and difficult parental challenges, are no doubt prone to food and nutrition insecurity and therefore, malnutrition. Without nutrition intervention, anaemia and micronutrient deficiencies may compromise the health of the elderly and, consequently, their ability to meet the realities of this new and additional care-giving burden; but even beyond this, contemporary principles of ethical reasoning, which are being influenced by the human rights perspective (i.e. the right of all to adequate nutrition and food security) justify the need to target elderly people living under circumstances similar to those found in this study, for nutrition intervention programmes to address these deficiencies.

\section{RECOMMENDATIONS}

This paper assessed the prevalence of anaemia of a low-income elderly community in South Africa. The findings indicate a high risk of folate and vitamin $B_{12}$ deficiency with a resultant prevalence of macrocytic anaemia in this community.

All maize meal, the most consumed staple food, as well as wheat flour, used for bread, has been fortified in South Africa since 2004 [Department of Health (DoH), 2002]. Fortificants for both maize meal and wheat flour include $7,15 \mathrm{~g}$ of folic acid and $178,57 \mathrm{~g}$ of electrolytic iron per kilogram (DoH, 2002:3). Food fortification may be one of the solutions to address anaemia in this elderly community, however, other solutions should also be designed and implemented in the context of this reality. The results of this study will form the basis for planning sustainable community- based intervention strategies to improve the nutritional status specifically related to anaemia of this elderly community. These include dietary intervention strategies involving dietary diversification, particularly with respect to enhancing intake of total bio-available iron, folate and vitamin $B_{12}$ by increasing intakes of spinach (folate, iron), broccoli (folate), dried beans (folate, iron), organ meat (iron, vitamin $B_{12}$ ), eggs (iron, vitamin $\mathrm{B}_{12}$ ), milk (vitamin $\mathrm{B}_{12}$ ) and chicken (iron). This can be promoted through home gardening projects, as well as raising chickens for meat and eggs, and goats for milk.

Furthermore, nutrition education is necessary to educate the elderly in this and other communities in order to modify their food procurement, preparation and meal patterns to address the prevalence of anaemia and other micronutrient deficiencies. Counselling on food procurement, preparation and meal planning skills should thus accompany nutrition education.

\section{REFERENCES}

ALLAIN, TJ, GOMO, ZAR, WILSON, AO, NDEMERA, B, ADAMCHAK, DJ \& MATENGA, JA. 1997. Anaemia, macrocytosis, vitamin $B_{12}$ and folate levels in elderly Zimbabweans. Central African Journal of Medicine 43(11):325-327.

CARLSON, TH. 2004. Laboratory data in nutrition assessment. In MAHAN, LK \& ESCOTT-STUMP, S (eds). Krause's food, nutrition and diet therapy. $11^{\text {th }}$ ed. Philadelphia. Saunders.

CHARLTON, KE, KRUGER, M, LABADARIOS, D, WOLMARANS, P \& ARONSON I. 1997. Iron, folate and vitamin B12 status of an elderly South African population. European Journal of Clinical Nutrition 51:424-430.

CHARLTON, KE \& ROSE, D. 2001. Nutrition among older adults in Africa: the situation at the beginning of the millennium. Journal of Nutrition 131(9): 2424S$2428 S$.

CHAVES, PH, CARLSON, MC, FERRUCCI, L, GURALNIK, JM, SEMBA, R \& FRIED, LP. 2006. Association between mild anemia and executive function impairment in community-dwelling older women: the Women's Health and Aging Study II. Journal of the American Geriatric Society 54:1429-1435.

DANNHAUSER, A, BESTER, CJ, JOUBERT, G, BADENHORST, PN, SLABBER, M, BADENHORST, AM, DU TOIT, E, BARNARD, HC, BOTHA, P \& NOGABE, L. 2000. Nutritional status of preschool children in informal settlement areas near Bloemfontein, South Africa. Public Health Nutrition 3(3):303-312.

DEPARTMENT OF HEALTH (DoH). 2002. Foodstuffs, cosmetics and disinfectants act, 1972 (Act no 54 of 1974). Regulations relating to the fortification of foodstuffs. Available at: www.doh.gov.za/docs/regulations/ foodstuff/fortification.html. Accessed on: 08 November 2006.

DHARMARAJAN, TS \& NORKUS, EP. 2004. Mild anemia and the risk of falls in older adults from nursing homes and the community. Journal of the American Medical Directors Association 5:395-400.

EL-SAYED, N, GAD, A, NOFAL, L, ZEID, A, EL- 
MORSHEDY, H \& EL-WASEEF, S. 1999. Assessment of the prevalence and potential determinants of nutritional anaemia in Upper Egypt. Food and Nutrition Bulletin 20(4):50-56.

ENGELBRECHT, K \& DU RAND, P. 2001. Status of frail elderly black people in informal settlements. South Africa's continuing medical education monthly 18(10):828-833.

EZEKOWITZ, JA, MCALISTER, FA \& ARMSTRONG, PW. 2003. Anemia is common in heart failure and is associated with poor outcomes: insights from a cohort of 12065 patients with new-onset heart failure. Circulation 107:223- 225.

FOOD AND AGRICULTURE ORGANIZATION OF THE UNITED NATIONS (FAO) \& WORLD HEALTH ORGANIZATION (WHO). 2002. Human Vitamin and Mineral Requirements Report of a joint FAO/WHO expert consultation. Rome. FAO.

GIBSON, RS. 2005. Principles of nutritional assessment. $2^{\text {nd }}$ ed. New York. Oxford University Press.

GIBSON, RS \& FERGUSON, EL. 2000. An interactive 24-hour recall for assessing the adequacy of iron and zinc intakes in developing countries. Available on line. www.ilsi.org/hni.html. Accessed on 12 August 2007.

GONZALEZ-GROSS, M, SOLA, R, ALBERS, U, BARRIOS, L, ALDER, M, CASTILLO, MJ \& PIETRI, K. 2007. 13-Vitamins and homocysteine in Spanish institutionalized elderly. International Journal for Vitamin and Nutrition Research 77(1): 22-23.

GURALNIK, JM, EISENSTAEDT, RS, FERRUCCI, L, KLEIN, HG \& WOODMAN, RC. 2004. Prevalence of anemia in persons 65 years and older in the United States: evidence for a high rate of unexplained anemia. Blood 15(104):2263-2268.

HOFFBRAND, AV, PETTIT, JE \& MOSS, PAH. 2001 Essential Haematology. $4^{\text {th }}$ ed. Oxford. Blackwell Science Publishing.

HORWICH, TB, FONAROW, GC, HAMILTON, MA, MACLELLAN, WR \& BORENSTEIN, J. 2002. Anemia is associated with worse symptoms, greater impairment in functional capacity and a significant increase in mortality in patients with advanced heart failure. Journal of the American College of Cardiology 39:1780-1786.

HUGO-HAMMAN, CT, KIBEL, MA, MICHIE, CA \& YACH, D. 1987. Nutrition status of pre-school children in a Cape Town township. South African Medical Journal 72:353-5.

INSTITUTE OF MEDICINE. 2003. Dietary Reference Intakes. Food and Nutrition Board. Washington, DC. National Academy Press.

IZAKS, GJ, WESTENDORP, RGJ \& KNOOK, DL. 1999. The definition of anemia in older persons. Journal of the American Medical Association 281:17141717.

JOHNSON, S \& VAN DER WESTHUYZEN, J. 1989. Nutritional evaluation of the black elderly in a rural village. South African Journal of Food Science and Nutrition 1(3):23-8.
LOIKAS, S, KOKIEN, P, IRJALA, K, LOPPONEN, M, ISOAHO R, KIVELA, SL \& PELLINIEMI, TT. 2007. Vitamin B12 deficiency in the aged: a populationbased study. Age and ageing 36 (2):177-183.

MARAIS, ML, MARAIS, D \& LABADARIOS, D. 2007. Assessment of nutritional status of older people in homes for the aged in Somerset-West. South African Journal of Clinical Nutrition 20(3):102-108.

OLDEWAGE-THERON, WH, DICKS, EG, NAPIER, CE \& RUTENGWE, R. 2004. A community-based integrated nutrition research programme to alleviate poverty: baseline survey. Public Health 119:312-20.

OLDEWAGE-THERON, WH, DICKS, EG \& NAPIER, CE. 2006. Poverty, household food insecurity and nutrition: Coping strategies in an informal settlement in the Vaal Triangle, South Africa. Public Health 120:795 -804 .

PENNINX, BW, GURALNIK, JM, ONDER, G, FERRUCCI, L, WALLACE, RB \& PAHOR, M. 2003. Anemia and decline in physical performance among older persons. American Journal of Medicine 115:104-10.

ROSS, SD, FAHRBACH, K, FRAME, D, SCHEYE, R, CONNELLY, JE \& GLASPY, J. 2003. The effect of anemia treatment on selected health-related quality-of -life domains: a systematic review. Clinical Therapies 25:1786-1805.

SARGENT, JD, STUKEL, TA, DALTON, MA, FREEMAN, JL \& BROWN, MJ. 1996. Iron deficiency in Massachusetts communities: socioeconomic and demographic risk factors among children. American Journal of Public Health 86:544 - 50.

STEENSMA, DP \& TEFFERI, A. 2007. Anemia in the elderly: How should we define it, when does it matter, and what can be done? Mayo Clinical Proceedings 82 (8):958-966.

STOPLER, T. 2004. Medical nutrition therapy for anaemia. In MAHAN, LK \& ESCOTT-STUMP, S (eds). Krause's food, nutrition and diet therapy. $11^{\text {th }}$ ed. Philadelphia. Saunders.

SOUTH AFRICAN MEDICAL RESEARCH COUNCIL. www.bloodbook.com/ranges.hmtl. Accessed 24 Feb 2008.

THE SURVEY SYSTEM. Sample size calculator. Available at http://www.surveysystem.com/ssformu.htm. (Accessed on 10 March 2007)

UNITED NATIONS CHILDREN FUND (UNICEF). 2003. Africa's orphaned generations. Available on line. http://www.unicef.org/publications/index_16271.html. Accessed on 29 June 2006.

VORSTER, HH, OOSTHUIZEN, W, JERLING, JC, VELDMAN, FJ \& BURGER, HM. 1997. The Nutritional Status of South Africans: A review of the literature from 1975-1996. Durban. Health Systems Trust. Available on line. http://www.healthlink.org.za/hst. Accessed on 20 November 2006.

WORLD HEALTH ORGANISATION (WHO). 2001. Iron deficiency anaemia - assessment, prevention and control - A guide for programme managers $\mathrm{WHO} /$ NHD/01.3. Geneva. WHO. Available on line www.who.int/entity/nutrition/publications/WHO_WFP_UNICEFstatement.pdf. Accessed 15 October 2007. 